Jacek Puchalski

\title{
Źródła do historii bibliotek pierwszej połowy XX w. a problemy ich klasyfikacji*
}

ak podkreślała Marianna Mlekicka, historia bibliotek i bibliotekarstwa ma wtasne przedmioty badań, metodę i podstawę źródtowa ${ }^{1}$. Dlatego też pojawilo się szereg klasyfikacji żródeł do dziejów książki, w tym bibliotek. Jedna z nich jest podział I.E. Barenbauma opublikowany w pracy Istorija knigi w $1971 \mathrm{r}^{2}{ }^{2}$, który wśród najważniejszych grup żródeł do historii książki wymieniał:

1. same książki ujawniające swą treść i wiele danych bibliograficznych,

2. materiały bibliograficzne (spisy, katalogi, wykazy, reklamy i in.),

3. materiały statystyczne,

4. drukowane źródła dokumentalne i narracyjne,

5. materiały archiwalne,

6. materiały prasowe,

7. rozprawy z historii książki i dyscyplin pokrewnych.

Jest to klasyfikacja o dużym stopniu ogólności, charakteryzująca się brakiem wyłączności zakresów - np. potraktowano odrębnie drukowane źródta narracyjne i materiaty prasowe. Ponadto autor zaliczył do źródeł opracowania (rozprawy z hisiorii ksiazkki i dyscyplin pokrewnych), co jest niezgodne z przyjętym pojęciem źródła historycznego ${ }^{3}$. W wypadku historii bibliotek pomija m.in. decydujący, moim zdaniem, aspekt twórcy źródła, a także calą grupę źródeł niepisanych, np. źródła ikonograficzne.

Kazimiera Maleczyńska w odniesieniu do swoich badań nad historią książki i bibliotek okresu renesansu przyjęla określenie źródła do dziejów bibliotek jako śladu istnienia i działalności bibliotek. Wyróżniła wśród nich źródła pisane i niepisane, do których zaliczyła zabytki kultury materialnej. Źródła pisane podzieliła natomiast na archiwalne i biblioteczne, nawiązując do podziału Jerzego Topolskiego na żródła bezpośrednie i pośrednie ${ }^{4}$.

\footnotetext{
* Niniejszy artykul jest częścią większego opracowania.
} 
Kolejne klasyfikacje źródeł omówił Krzysztof Migon w artykule Problematyka źródłoznawcza w bibliologii ${ }^{5}$. Pierwsza z nich, opublikowana przez Alexandra Greguletza ${ }^{6}$, dzieliła źródła do historii bibliotek na cztery grupy:

1. materiały oficjalne, dokumenty państwowe, które określają podstawowe linie rozwojowe bibliotekarstwa,

2. materiały archiwalne i żródła drukowane, które zawierają informacje o powstaniu i rozwoju bibliotek, ich pracy, o dzialalności poszczególnych organizatorów bibliotekarstwa (np. także materiały statystyczne, dokumenty organizacji naukowych,

3. katalogi biblioteczne, sprawozdania rachunkowe, sprawozdania z działalności, formularze czytelnicze i inne (drukowane materiały o dzialalności bibliotek; pamiętniki itd.), zbiory biblioteczne lub ich części,

4. opracowania $z$ historii bibliotekarstwa, które w całości lub częściowo opierają się na zaginionych źródłach.

A. Greguletz rozwinął powyższą klasyfikację, dzieląc źródła:

1. według miejsca w systemie relacji społecznych:

a. dokumenty oficjalne (organizacji panstwowych i społecznych),

b. dokumenty osobiste (listy, dzienniki, biografie, opinie);

2. według sposobu wykonania technicznego:

a. piśmienne, tj. drukowane, rękopiśmienne, maszynopisowe,

b. dokumenty przedstawiające (darstellende) (plakaty, mikrofilmy, taśmy filmowe),

c. dokumenty dźwiękowe (płyty, taśmy);

3. według chronologii:

a. bieżące dokumenty biblioteczne,

b. archiwalia;

4. według zawartości informacyjnej:

a. materiały prymarne,

b. materiały wtórne;

5. według sposobu utrwalenia i opracowania informacji:

a. sformalizowane materiały (np. kwestionariusze do badań socjologicznych),

b. niesformalizowane materiały (wywiady, dzienniki, listy);

6. z socjologicznego punktu widzenia:

a. materiały oficjalne,

b. materiały społeczno-psychologiczne (listy, dzienniki i biografie).

Nie jest to precyzyjna i pełna klasyfikacja. Pomija m.in. takie źródła niepisane jak budownictwo i wyposażenie biblioteczne, stosuje nieprecyzyjnie kryteria podziału (np. chronologiczne). K. Migon odnotowuje także bardziej tradycyjny po- 
dział autorstwa Andreasa Anderhuba, przedstawiony w 1979 r. ${ }^{7}$, dzielącego źródła na:

- tradycję (kroniki bibliotek, wspomnienia, dokumentacja fotograficzna itd.),

- pomniki (same zbiory biblioteczne i ich katalogi),

- pozostałości (materialne, niematerialne i pisane).

Sam K. Migoń zajął się tylko ważniejszymi zagadnieniami źródel wiedzy o książce i jej kulturze. W pierwszej kolejności przeanalizował ujęcie typologiczne, uwzględniające podziały przyjęte w ogólnym źródłoznawstwie historycznym. Autor, zdając sobie sprawę $\mathrm{z}$ dużej ogólności takiego podejścia, wyróżnil wśród żródeł bibliologicznych dwie zasadnicze grupy:

- źródła niepisane (przedmioty, urządzenia techniczne, narzędzia, maszyny, budowle i ich wyposażenie, a także źródła ikonograficzne: artystyczne lub techniczne odbicie owych zabytków materialnych, m.in. ekslibrisy),

- źródła pisane (dokumenty graficzne), czyli źródła archiwalne, dokumentacyjne, ktore powstały $w$ wyniku zwiazanej $z$ ksiażkq $i$ jej instytucjami działalności władz politycznych i gospodarczych, instytucji państwowych, kulturalnych, naukowych, sqdowych.

Do źródeł pisanych K. Migoń zaliczył także:

- dokumenty autobiograficzne - czyli pamiętnikarstwo i korespondencję - przede wszystkim spuścizny pracowników książki, ale także i te, które wyszły spod piór ludzi niezwiązanych z książką profesjonalnie, a które ważne będa glównie jako świadectwa recepcji książki,

- źródła statystyczne to najmłodsza stosunkowo kategoria źródeł, obejmująca dane dotyczące książki w oficjalnych zestawieniach statystycznych,

- żródła bibliologiczne - materiały powstające w kręgu instytucji książki, a służące jej reklamie, informacji o niej, jej udostępnianiu i wykorzystywaniu, pozbawione jednak charakteru żródeł dokumentacyjnych czy literackich, w tym takie jak notatka proweniencyjna lub glossa do tekstu, dokumentacja biblioteczna: katalogi, karty książki i czytelnika, regulaminy biblioteczne, książki wypożyczeń i rewersy, wykazy nowych nabytków, wreszcie także spisy bibliograficzne. Do tej grupy źródeł bibliologicznych autor zaliczył także wszelkie dawne teksty naukowe i popularnonaukowe z zakresu nauki o książce i bibliotece. Inaczej mówiąc: opracowania, których historycy nie zaliczają do żródel historycznych.

Dalej K. Migoń stwierdza, że wszystkie te kategorie źródeł można podzielić na żródła bezpośrednie i pośrednie, zamierzone i niezamierzone, za Gerardem Labuda zaś uznać źródła dokumentacyjne, statystyczne, a w części też bibliologiczne za żródła socjotechniczne, natomiast źródla literackie i autobiograficzne - za 
psychotechniczne. W tym ujęciu sama książka jako przedıniot materialny będzie źródtem ergotechnicznym, z racji zaś swej treści, artystycznego ukształtowania (...) będzie źródtem psychotechnicznym.

W konkluzji artykułu K. Migoń wyodrębnił spośród ogółu źródeł historycznych grupę żródeł bibliologicznych, które shiża przede wszystkim badaniom księgoznawczym, a następnie też badaniom $w$ ramach innych nauk historycznych. Zaliczył do nich:

1. książki (jako przedmioty materialne wraz z intelektualną zawartością),

a. pojedyncze książki w całości,

b. części książek (mechanicznie oderwane),

c. elementy książek (świadomie wyodrębnione w badaniach),

d. zbiory książek (repertuar wydawniczy, asortyment księgarni, zbiór biblioteczny, kanon lektury proponowanej, rzeczywista lektura),

2. informacje o funkcjonowaniu instytucji książki i całym systemie książki (o wydawcach i wydawnictwach, drukarzach i drukarniach, o księgarzach i księgarniach itd.),

3. wiadomości o odbiorcach (adresatach, użytkownikach, czytelnikach) książek.

W badaniach bibliologów grupę wymienionych źródeł uzupełniają liczne źródła pozabibliologiczne. Według K. Migonia związane to jest z potrzebą ujęć opartych na kontekstem politycznym, ekonomicznym, technicznym, a głównie kulturalny, oraz z poszerzaniem się pola badawczego nauki o książce i łączeniem go z problematyką innych nauk.

W tym samym tomie „Studiów o Książce” z 1985 r. ukazał się artykuł Marii Kocójowej ${ }^{8}$. Nawiązując do klasyfikacji źródeł Marcelego Handelsmana autorka stwierdziła, że jego podział na źródła pisane i niepisane jest czytelny dla bibliologów. Podkreśliła, że źródła pisane, czyli właściwe źródła historyczne, par excellence dokumenty historyczne, stanowiące podstawę dokumentacji też bibliologicznej, nie sa łatwe do znalezienia w archiwach i bibliotekach. Szczególne trudności sprawiają poszukiwania archiwalne, do których niezbędna jest znajomość zawartości zespołów archiwalnych. Dalej autorka podkreślała braki w informacji bibliologicznej o źródlach adresowanych, wymieniając w tym kontekście trzy ich podstawowe grupy:

a) adresowane do odbiorcy - współczesne autorowi źródła (np. listy, sprawozdania, protokoły, ogłoszenia reklamowe, katalogi, listy subskrypcyjne),

b) adresowane do potomności (prawa własności, napisy nagrobne),

c) adresowane do historyka (większość pamiętników).

Odnotowując dwie tendencje kształtowania podstawy źródłowej w badaniach bibliologicznych nad okresem niewoli narodowej, autorka stwierdziła: 
- dążenie do pełnego opanowania materiału źródłowego,

- tendencję selektywną, poszukiwanie dróg zawężania podstawy źródłowej.

M. Kocójowa stwierdziła m.in., że największe możliwości wykorzystywania materiału źródłowego stwarza komunikacyjna orientacja bibliologii.

Kolejną analizę żródeł do badań bibliologicznych zawiera opracowanie Juliana Fercza i Aleksandry Niemczykowej ${ }^{9}$. Autorzy przywołali tradycyjny podział źródeł historycznych na źródła bezpośrednie, czyli dokumenty, które powstały w toku badanego wydarzenia czy procesu i w bezpośrednim z nim związku (np. regulaminy biblioteczne), oraz pośrednie, utrwalające ślady minionych wydarzeń w jakiś sposób zinterpretowane przez twórców źródeł w celu utrwalenia informacji o jakimś wydarzeniu i przekazania jej osobom postronnym (np. listy prywatne) lub potomności (np. pamiętniki).

Kolejny podział to źródła pisane (opublikowane i rękopiśmienne) i niepisane, przy czym ten sam obiekt może być badany jako źródto pisane i niepisane, np. ksiażka może być źródtem pisanym ze względu na swq treść, ale jest źródtem niepisanym, gdy badamy ja ze względu na jej postać materialną. Dalej autorzy zwracają uwagę na to, że granica między opracowaniami a źródtami niekiedy się zaciera, wymieniając w tym kontekście spisy bibliograficzne i urzędowe zestawienia statystyczne.

W konkluzji stwierdzaja:

Bibliologia, jako nauka wewnętrznie bardzo złożona, poshuguje się różnorodna bazq źródtowq. Badacz ksiażki czerpie wiedzę zarówno z obserwacji interesujacych go instvtucji i procesów, jak i ze źródet umyślnie przez siebie tworzonych oraz ze źródet historycznych wszelkiego rodzaju.

Klasyfikując dalej źródła do badań bibliologicznych, autorzy wyróżniają:

1. Źródla bezpośrednie pisane, czyli głównie archiwalne, tj. akta urzędowe przechowywane w archiwach lub też jeszcze praktycznie wykorzystywane, lecz kwalifikujące się do przekazania ich do archiwum po wygaśnięciu ich wartości użytkowej. Tworzą one główny zasób źródeł do badania instytucji, w toku działalności których powstały, w tym:

- zamówienia i rachunki, księgi rachunkowe, listy płac, inwentarze (spisy majątkowe) itp., zawierające informacje m.in. o wyposażeniu biblioteki, o jej stanie finansowym, o jej działalności podstawowej: np. o opracowaniu i gromadzeniu zbiorów,

- plany i sprawozdania, protokoły posiedzen, regulaminy pracy, biblioteczne regulaminy udostępniania,

- akta personalne, informujące o skladzie osobowym i strukturze organizacyjnej instytucji, ale także o organizacji, przebiegu, atmosferze i stylu pracy, jak również o możliwościach finansowych instytucji,

- korespondencja urzędowa, pozwalająca na rekonstrukcję kontaktów i zależności między instytucjami realizującymi procesy tworzenia 
i obiegu społecznego książki a instytucjami wobec nich nadrzędnymi, nadzorującymi je, współpracującymi i wspierającymi. Wymienic tu można organy administracji państwowej i komunalnej, władze oświatowe i organy cenzury, wladze i instytucje kościelne, instytucje posiadajace własne biblioteki;

- wszelkiego rodzaju akta instytucji posiadajacych swoje biblioteki, dotyczące działalności tych bibliotek,

- akta, w których działalności nie wyodrębnia się nurt specjalnie poświęcony sprawom książki, np. akta sądowe i notarialne czy akta stanu cywilnego. Zawieraja jednak informacje nie tylko o działalności instytucji, ale i o osobach, np. właścicielach księgozbiorów prywatnych (testamenty, inwentarze ruchomości osób zmarłych oraz akta związane $z$ licytacjami i transakcjami handlowymi, których przedmiotem były książki),

- rękopiśmienne zbiory bibliotek,

- katalogi biblioteczne, czy to kartkowe, czy jeszcze starsze, spisywane w postaci ksiąg. Są one, rzecz jasna, cennymi źródłami bezpośrednimi do badania historii bibliotek (szczególnie tych, których zbiory uległy zniszczeniu) i techniki bibliotecznej,

- źródła, które wprawdzie mają charakter archiwalny, lecz w praktyce nie są archiwizowane ze względu na małą zawartość informacji w poszczególnych dokumentach, a dużą liczebność całego ich zbioru; przykładami mogą być rewersy biblioteczne, karty książki i czytelnika itp.;

- według J. Fercza i A. Niemczykowej nie zaliczamy natomiast do źródeł archiwalnych takich źródeł bezpośrednich pisanych, które natychmiast po ich spisaniu były podawane do wiadomości publicznej drukiem. Kontynuując, autorzy Podstaw nauki o ksiqżce, bibliotece $i$ informacji naukowej zaliczają do tej grupy źródeł np. rozporządzenia władz ogłaszane w tzw. dziennikach urzędowych, drukowane regulaminy biblioteczne lub wykazy nabytków, publikowane przez komitety normalizacyjne krajowe lub międzynarodowe normy wydawnicze, bibliograficzne czy biblioteczne,

- wśród opublikowanych bezpośrednich źródeł pisanych na szczególna uwagę zasługują ogłoszenia prasowe oraz drukowane katalogi np. licytowanych księgozbiorów i drukowane katalogi bibliotek,

- bezpośrednim źródłem pisanym do dziejów bibliotek jest też sama książka jako świadectwo istnienia określonego księgozbioru, dzięki zachowanym znakom wlasnościowym i jako element całego księgozbioru biblioteki.

2. Źródła bezpośrednie niepisane

- książka w sensie materialnym, 
- zachowane wyposażenie dawnych i współczesnych pomieszczeń bibliotecznych: półki i szafy, wyposażenie czytelni, aparaty reprograficzne, pomieszczenia biblioteczne. J. Fercz i A. Niemczykowa zaliczyli do tej grupy także plany budynków bibliotecznych sporzadzone przez architekta, któremu powierzono budowę biblioteki. Wydaje się, że nie jest to uzasadnione, ponieważ są to dokumenty w dużej części także pisane.

3. Źródła pośrednie pisane:

- relacje prywatne o wszelkich sprawach związanych z książką,

- relacje publiczne o wszelkich sprawach zwiazanych z książką,

- publikacje informujące o warunkach użytkowania książki,

- literatura fachowa: podręczniki, poradniki, czasopisma,

- zestawienia statystyczne, publikowane przez instytucje państwowe lub stowarzyszenia fachowe i kulturalne,

- źródla literackie.

4. Źródła pośrednie niepisane: ikonografia przedstawiająca budynki i wnętrza biblioteczne, makiety gmachów bibliotecznych, fotografie.

Powyższa klasyfikacja wymaga kilku słów komentarza. Oparta jest na znanej i dyskusyjnej klasyfikacji Jerzego Topolskiego ${ }^{10}$. Jej autorzy zaliczyli do źródeł bezpośrednich, w których według J. Topolskiego nie ma problemu badania wiarogodności informatora, szereg źródeł, których wiarygodność (autorów) musi być sprawdzona. J. Fercz i A. Niemczykowa sami piszą o tym, wskazując na przykład rocznego sprawozdania z dzialalności biblioteki, które może zawierać celowo zawyżone dane, aby w lepszym świetle przedstawić funkcjonowanie placówki. Podobne przykłady można mnożyć. Dyskusyjna może być wiarygodność akt personalnych, zawierających opinie osób trzecich o pracowniku biblioteki, to samo dotyczy informacji zawartych we wszelkiego rodzaju korespondencji, jak i katalogów bibliotecznych, które w przypadku dużych bibliotek, posiadających zbiory specjalne, nie zawsze muszą opisywać całość zbiorów, lecz tylko ich skatalogowany fragment. W tym ostatnim wypadku każdy bibliolog zdaje sobie sprawę, że zwłaszcza w wypadku zbiorów specjalnych opis katalogowy może zawierać błędy. Praktycznie więc biorąc: wszelkie źródła, w których wyrażana jest opinia własna ich twórcy lub które mają charakter opracowania, innymi słowy, mają informować - są żródłami pośrednimi, tj. winno się sprawdzić wiarygodność informatora.

Przedstawione wyżej najważniejsze klasyfikacje źródeł bibliologicznych przydatnych w badaniach nad historia bibliotek mają charakter ogólny, tj. nie oddają w pełni specyfiki źródeł do historii bibliotek pierwszej połowy XX w. Baza źródlowa do badań nad historia bibliotek i księgozbiorów prywatnych tego okresu jest ogromna i bardzo zróżnicowana ${ }^{11}$. Źródła możliwe do wykorzystania w bada- 
niach nad dziejami bibliotek zostały szeroko opisane, jednak bez ich pełnej analizy z punktu widzenia źródłoznawstwa.

Na podstawie literatury przedmiotu ${ }^{12}$ oraz prac dokumentacyjnych związanych z działalnością Biura Pełnomocnika Rządu do Spraw Polskiego Dziedzictwa Kulturalnego za Granica, od 2002 r. Departamentu Dziedzictwa Narodowego Ministerstwa Kultury, które od 1992 r. prowadzi dokumentację strat wojennych bibliotek, można wyodrębnić wiele typów źródeł do dziejów bibliotek i księgozbiorów prywatnych. Tworzą zasób żródeł do historii bibliotek w pierwszej połowie XX w. Aby wstępnie ten zasób uporządkować, można posłużyć się klasycznym ich podziałem na źródła pisane i niepisane ${ }^{13}$.

I. Źródła biblioteczne - źródła wytworzone przez biblioteki i przechowywane w bibliotekach. Należą do nich:

1. Źródla pisane (drukowane i rękopiśmienne)

- księgozbiory lub ich fragmenty, bądź pojedyncze książki zawierające znaki wlasnościowe jako zbiory tekstów, informujące nas o zawartości treściowej zbiorów bibliotecznych,

- dokumenty wytworzone i publikowane współcześnie przez biblioteki, przechowywane w bibliotekach, dotyczące ich współczesności i historii, w tym: statuty, regulaminy, sprawozdania, zestawienia w tym liczbowe, wzory formularzy bibliotecznych, wykazy nabytków, druki obiegowe, zamówienia, rachunki, księgi rachunkowe, listy płac, inwentarze (spisy majątkowe) plany i sprawozdania, protokoły posiedzen, regulaminy pracy, biblioteczne regulaminy udostępniania, rewersy biblioteczne, karty ksiażki i czytelnika, zestawienia statystyczne itp., akta personalne (podania o przyjęcie do pracy, nominacje i wypowiedzenia, zawiadomienia o awansach i upomnienia, zakresy obowiązków i in.), korespondencja wychodząca i przychodząca do bibliotek, darowizny, kwestionariusze i ankiety wypełniane przez biblioteki i właścicieli, bibliotekarzy księgozbiorów prywatnych, plany architektoniczne, projekty wystroju lokali bibliotecznych,

- instrukcje, przepisy i normy opracowania zbiorów,

- katalogi i inwentarze książek.

2. Źródła niepisane

- źródła ikonograficzne: fotografie, grafika,

- pozostałości rzeczowe: ksiazżka w sensie materialnym, a także zachowane budynki, pomieszczenia, wyposażenie biblioteczne,

- żródła audiowizualne: filmy, nagrania radiowe, magnetofonowe, superekslibrisy, ekslibrisy, pieczęcie. 
II. Źródla archiwalne - źródla wytworzone przez biblioteki lub instytucje związane różnymi relacjami z bibliotekami, dotyczące bibliotek, przechowywane $w$ archiwach.

1. Źródła pisane - to dokumenty instytucji państwowych, samorządowych, społecznych, prywatnych (np. fundacji), naukowych, m.in. sprawozdania z działalności organizacji i instytucji, w tym: zestawienia, także liczbowe, sprawozdania zbiorcze, obejmujące swym zasięgiem większe terytoria i całe grupy placówek, oraz indywidualne - odnoszące się wyłacznie do poszczególnych jednostek, kroniki, korespondencja urzędowa organów administracji państwowej i samorządowej, władz i instytucji naukowych, oświatowych, kościelnych, społecznych, prywatnych, a także akta sądowe i notarialne czy akta stanu cywilnego, z takimi dokumentami jak: testamenty, inwentarze, akta związane z licytacjami i transakcjami handlowymi, plany architektoniczne, projekty wystroju lokali bibliotecznych.

2. Źródła niepisane

- żrodła ikonograficzne: fotografie, grafika,

- żródła audio-wizualne: filmy, nagrania radiowe, magnetofonowe,

- superekslibrisy, ekslibrisy, pieczęcie.

III. Źródla instytucjonalne - źródła wytworzone przez instytucje związane różnymi relacjami z bibliotekami. Są to źródla dotyczące bibliotek, przechowywane w instytucjach, które je wytworzyły ${ }^{14}$.

1. Źródła pisane. Należą do nich m.in. raporty, zestawienia, także liczbowe, tzw. wydawnictwa urzędowe, zawierające różne informacje dotyczące bibliotek, plany architektoniczne, projekty wystroju lokali bibliotecznych;

2. Źródła niepisane

- źródła ikonograficzne: fotografie, grafika,

- źródła audiowizualne: filmy, nagrania radiowe, magnetofonowe,

- superekslibrisy, ekslibrisy, pieczęcie.

IV. Źródla nieinstytucjonalne - są to źródła nieaktowe wytworzone poza bibliotekami i instytucjami związanymi różnymi relacjami z bibliotekami.

1. Źródla pisane

- żrodla opisowe (narracyjne): wytworzone przede wszystkim przez bibliotekarzy i bibliologów notatki, biografie, pamiętniki, wspomnienia, korespondencja prywatna, relacje (czasopisma, zwlaszcza naukowe, dziedzinowe i specjalistyczne, gazety, dzienniki), a także m.in. przewodniki turystyczne,

- źródła literackie odnoszące się do bibliotek.

2. Źródła niepisane

- żródła ikonograficzne: fotografie, grafika, malarstwo, rzeźbiarstwo, 
- źródła audiowizualne: filmy, nagrania radiowe, magnetofonowe.

Powyższa próba typologii źródeł do historii bibliotek nie jest rozłączna, np. pewne typy źródeł znajdziemy równocześnie w źródłach bibliotecznych, archiwalnych, jak i instytucjonalnych czy nawet nieinstytucjonalnych - np. źródła o charakterze statystycznym. Co więcej, może się zdarzyć, że w tych czterech typach źródeł znajdziemy kopie tych samych dokumentów. Podobnie rzecz ma się z podziałem na źródła niepisane ikonograficzne i audiowizualne, które moga wystąpić we wszystkich wyróżnionych grupach żródeł. Sam podział źródeł na pisane i niepisane nie jest rozłączny, np. trudno zakwalifikować jednoznacznie superekslibrisy, które oprócz wyobrażenia ikonograficznego zawierają także tekst pisany. Z czasem źródła do historii bibliotek moga znależć się w internecie jako dokumenty multimedialne, ich zakwalifikowanie do źródeł pisanych lub niepisanych będzie niemożliwe.

Zachodzi pytanie, jak powyższa typologia ma się do dotychczasowych klasyfikacji źródeł historycznych. O podziale na źródła pisane i niepisane już wspominałem.

Według M. Handelsmana źródła pisane mają najważniejsze znaczenie (są to właściwe źródła historyczne) ${ }^{15}$. Podzielił je na:

- źródła opisowe: m.in. opisy pamiętnikarskie (noty, dzienniki, biografie, wspomnienia, pamiętniki właściwe), zbiory wiadomości, czasopisma (dzienniki, tygodniki, miesięczniki) - w mojej typologii odpowiadają im pisane źródła nieinstytucjonalne, w tym także korespondencja prywatna, o ile została wytworzona poza dana instytucją;

- źródła aktowe: źródła aktowe lub dokumentowe, korespondencja prywatna i publiczna, noty, materiały, wywody i wykładnie prawne, protokoły, zapiski kancelaryjne - w mojej typologii odpowiadają im pisane źródła biblioteczne (nawet księgozbiory lub ich fragmenty dokumentują istnienie danej biblioteki), archiwalne i instytucjonalne.

Stanisław Kościałkowski podzielił źródła ze względu na ich cechy zewnętrzne:

1. źródła niepisane, rzeczowe, pozostałościowe,

2. żródła pisane różnych rodzajów

a) źródła dokumentalne albo bezpośrednie obejmują dokumenty o charakterze prawnym lub urzędowym, a jednocześnie stanowią bezpośrednią część składową pewnych czynności urzędowych lub faktów, o których mówi ich treść, m.in. akta (sejmowe, sadowe, kościelne, szkolne, administracyjne, skarbowe, wojskowe, instytucji przemysłowych, handlowych, bankowych, zrzeszeń kulturalnych, społecznych, dobroczynnych i dobra ogólnego) - w mojej typologii odpowiadają im pisane źródła biblioteczne, archiwalne i instytucjonalne, 
b) źródła narracyjne (historiograficzne) albo pośrednie są to takie źródła, które mówią nam o pewnych faktach, zawierają relacje pośrednie o tych faktach, lecz częścią składową bezpośrednią tych faktów bynajmniej nie sa, m.in.: kroniki, pamiętniki, wspomnienia, dzienniki, autobiografie, czasopisma, pisma polemiczne - w mojej typologii odpowiadaja im pisane żródla nieinstytucjonalne.

S. Kościałkowski zdecydował się natomiast wyodrębnić źródła epistolarne albo listowe zajmujące według niego miejsce pośrednie między źródłami dokumentalnymi a narracyjnymi. Ja umieściłem je w różnych grupach źródeł ze względu na miejsce ich wytworzenia, gdyż mają inne znaczenie, powstając jako wynik działalności danej instytucji i stanowiąc część jej akt, a inne - gdy są wynikiem prywatnej, pozaurzędowej korespondencji ${ }^{16}$.

Kolejną klasyfikacja, do której nawiązuje przedstawiona wyżej typologia źródeł do historii bibliotek, jest podział Jerzego Serczyka, wyróżniajacego wśród źródeł pisanych:

1. opisowe (narracyjne, opowiadające), w tym m.in. dzieła historiograficzne, biografie, pamiętniki, wspomnienia, relacje oraz całą twórczość publicystyczną (czasopisma, gazety, dzienniki, ulotki, materiały propagandowe itp.) i korespondencję prywatną,

2. dokumentowe i aktowe, czyli wszelkiego rodzaju dokumenty jak i zbiory akt powstałe w wyniku działalności urzędów i instytucji państwowych i spolecznych (łącznie $z$ instytucjami religijnymi). Zaliczyć do nich można także akta prywatne, poszczególnych osób lub grup ludzkich. Należa tu zatem np. akta władz administracyjnych, skarbowe, sadowe, wojskowe, szkolne, kościelne, akta zrzeszeń i organizacji ${ }^{17}$.

Jednak w wypadku podziału źródeł do historii XIX i XX w. Ireneusz Ihnatowicz uważał, że nie należy budować klasyfikacji zasobu źródłowego, lecz raczej przeprowadzić typologię źródeł pozwalająca wyodrębnić cechy charakterystyczne dla epoki. Autor wymieniał w tym kontekście podział zasobu na źródła:

- archiwalne,

- biblioteczne i muzealne,

- urzędowe i nieurzędowe,

- rękopiśmienne, drukowane, dokumentację mechaniczną (źródła wytworzone za pomocą zapisu mechanicznego, a więc fotografie, nagrania itp. $)^{18}$.

Podobna klasyfikacja odbiega od systematyk źródeł omówionych powyżej. Wynika to ze specyfiki żródel historycznych do czasów najnowszych, w których pojawiły się takie nowe formy jak film, fotografia, nagranie magnetofonowe ${ }^{19}$, a obecnie multimedia. Te rodzaje źródeł nie mieszczą się w podziałach przyjmujących za podstawę cechy formalne źródła. 
Badając np. historię najnowszą bibliotek, mamy również do czynienia ze źródłami powstającyni przy udziale samych historyków, np. z ankietą rozsyłaną do bibliotek przez Biuro Pełnomocnika Rządu ${ }^{20}$. W takim wypadku historyk ma wpływ na wiarygodność i zakres takiego źródła jako twórca kwestionariusza. Źródła dotyczące badanego okresu, które powstały przy udziale badaczy, ale i instytucji „obserwujących" biblioteki, zaliczamy do żródeł wywołanych przez historyka lub instytucję (gromadzenie relacji itp.). Ta grupa źródeł, charakterystyczna dla historii najnowszej, nie jest rejestrowana w niektórych podziałach źródeł historycznych ${ }^{21}$.

Biorac pod uwagę powyższe rozważania, wydaje się, że materiał źródłowy do historii bibliotek - ze względu na ich „instytucjonalność” - najwłaściwiej jest dzielić z punktu widzenia jego wytwórcy, a potem przechowywania i zawartości informacji źródłowych.

Właśnie w ten sposób próbowałem zbudować moją typologię źródel do historii bibliotek w pierwszej polowie XX w., zwracając uwagę w przede wszystkim na ich wytwórce, który często decyduje o wartości badawczej źródla, a potem na miejsce przechowywania źródeł - niezwykle istotne, bo wymaga wiedzy np. o organizacji archiwów, historii urzędów, instytucji, znajomości zasad gromadzenia i opracowania zbiorów archiwalnych.

W pewien sposób nawiązuję do koncepcji I. Ihnatowicza, który - jak już wspomniałem - uważał, że w wypadku źródeł do historii XIX i XX w. nie należy budować klasyfikacji zasobu źródłowego, lecz raczej przeprowadzić typologię źródel, pozwalającą wyodrębnić cechy charakterystyczne dla epoki ${ }^{22}$. Właśnie na wytwórcę, wystawcę źródła kładzie nacisk J. Topolski, proponując klasyfikację metodologiczną, zajmującą się miejscem źródła w tańcuchu komunikacyjnym: nadawca informacji, odbiorca, history $k^{23}$.

$\mathrm{Z}$ tego punktu widzenia źródła historyczne epoki najnowszej można według I. Ihnatowicza podzielić na kilka grup ${ }^{24}$.

A. Wystawca źródła jest w stosunku do odbiorcy w sytuacji uprzywilejowanej formalnie. Sa to zazwyczaj:

a) pytania o informacje zebrane przez adresata źródła $w$ drodze obserwacji spoleczeństwa lub innych obiektów,

b) normy nakazujące adresatowi jakieś działania.

W wypadku historii bibliotek jako przykład może posłużyć zarządzenie Wydzialu Bibliotek Ministerstwa Oświaty przesyłane w 1945 r. do kuratoriów okręgów szkolnych w sprawie rejestracji strat bibliotek razem z kwestionariuszem w sprawie strat i szkód w bibliotekach ${ }^{25}$.

B. Wystawca źródla jest podporządkowany odbiorcy.

Takie źródła nie zawierają $z$ reguły elementów normatywnych, lecz przede wszystkim informacje pierwotne - na przykład wypełnione przez biblioteki kwe- 
stionariusze, przesyłane do kuratoriów, a stamtąd do Ministerstwa Oświaty, w odpowiedzi na wyżej wspomniane zarządzenie ${ }^{26}$.

C. Obie strony - wystawca i odbiorca - są w sytuacji równorzędnej, tj. są od siebie niezależne. Można tu dostrzec zarówno żądania i normy każdej ze stron, jak i pytania o informacje pierwotne oraz odpowiedzi na te pytania - tak jak to było m.in. w wypadku kwerendy koordynowanej w latach 1975-1980 przez Bibliotekę Narodową, mającej na celu szczegółową rejestrację materiałów dotyczących emigracji i Polonii, w tym także dokumentów związanych z książką, a znajdujących się w archiwach krajowych ${ }^{27}$.

D. Istnieje twórca źródła, lecz samo źródlo nie jest do nikogo wyraźnie kierowane lub też, gdy nie jest w ogóle przeznaczone dla jakiegokolwiek odbioru. W tej grupie utrwalone być mogą zarówno pewne informacje, jak i normy. Do tej grupy źródeł można zaliczyć dokumenty rejestrujace jakiś stan rzeczy, np. biblioteczne rejestry dowodow wpływów.

Podobne grupy źródeł występują we wszystkich wyróżnionych powyżej rodzajach źródeł pisanych do dziejów bibliotek w pierwszej połowie XX w.: bibliotecznych, archiwalnych, instytucjonalnych i nieistytucjonalnych. Jest to istotna typologia, gdyż pokazuje na kierunek poszukiwań źródeł pierwotnych (z punktu widzenia wystawcy), których powinniśmy szukać w dokumentacji działalności poszczególnych jednostek organizacyjnych bibliotek. Powyższa typologia potwierdza także istnienie źródeł „wywolanych” przez instytucję nadrzędną. W wypadku badania takich źródeł należy mieć na uwadze, że instytucja „wywołująca” ma wpływ na źródło pierwotne jako autor kwestionariusza pytań.

Wreszcie omawiana typologia nawiązuje do wyróżnionych przez J. Topolskiego źródeł adresowanych, czyli nastawionych na komunikowanie, o których była mowa powyżej, oraz do koncepcji Aleksandra Świerzawskiego zakładającej podział źródeł na:

- źródła informacji niezamierzonej (przypadkowe), czyli wszelkie ślady naturalne (przypadkowe) informujace nas o przeszłości (...), jak i ślady sztuczne - wytwory dziatalności ludzkiej, np. budowle, narzędzia, przedmioty codziennego użtku itp. Te ostatnie powstaty wytacznie w celu użytkowym, bez myśli o tym, by przekazać informacje, jak osoby je użytkujace mieszkaty, pracowaty $c z y \dot{z} y t y^{28}$,

- żródła przekazujące celowo informacje zamierzone:

a) źródla pisane (tych jest najwięcej),

b) źródła obrazowe albo ikonograficzne (obrazy, rzeźby, dagerotypy, fotografie, filmy, mapy, plany),

c) żrodła słuchowe albo dźwiękowe (walce fonograficzne, płyty gramofonowe, taśmy magnetofonowe $)^{29}$. 
Wszystkie te podziały biorą pod uwagę aspekt komunikacyjny źródła, wpływający na ocenę jego wiarygodności. Ten problem próbowal rozwiązać J. Topolski, proponując swoją klasyfikację metodologiczną rozbudowującą teorię źródeł:

- pośrednich,

- bezpośrednich.

Według J. Topolskiego źródła bezpośrednie umożliwiaja poznanie bezpośrednie faktów (brak pośrednictwa osoby trzeciej wyklucza problem badania wiarogodności informatora, natomiast pozostaje konieczność badania autentyczności źródła).

Źródła pośrednie umożliwiają poznanie pośrednie przez znaki umowne (pismo, język i inne) mające na celu komunikowanie określonego stanu rzeczy (istnieje konieczność ich odczytywania). Ważną kwestią jest tutaj pośrednictwo osoby trzeciej (ewentualnie celowe), co powoduje konieczność badania wiarogodności informatora.

Według J. Topolskiego dalszy wewnętrzny podział żródeł bezpośrednich i pośrednich może być, zgodnie z preferowaną koncepcją, różny. Na przykład żródła bezpośrednie można podzielić na pisane i niepisane.

W ten sam sposób można podzielić źródła na pośrednie oraz na przeznaczone do celowego przekazywania informacji i przekazujące je bez takiego uprzednio założonego celu ${ }^{30}$. Założenie, że nie ma potrzeby badania wiarygodności źródeł bezpośrednich jest dyskusyjne. Na przykład, zdaniem Brygidy Kürbis, krytyce wewnętrznej (erudycyjnej - utożsamienie osób, sprawdzenie miejsca i czası akcji oraz jej przedmiotu, daje podstawe do przyjęcia jako pewne albo jako prawdopodobne, że sprawy utrwalone pismem lub podobnymi jemu śodkami, np. w obrazie filmowym lub na taśmie magnetycznej, rzeczywiście się rozegrały) podlegają także źródła niepisane (bezpośrednie): ikonograficzne oraz żródla posługujące się analogicznymi środkami jak pismo (np. rejestr żywej mowy na taśmie), a także źródła - przedmioty nieposiadające przekazu słownego, np. plany, narzędzia - to wszystko, co daje się rozeznać za pomocą odtworzenia rysunku - projektu ${ }^{31}$. Wypada się z tym stwierdzeniem zgodzić mając np. na uwadze, że na wiarygodność takich źródeł jak fotografia czy film mogą mieć wpływ m.in. ich twórcy ${ }^{32}$. Wydaje się, że najprościej i najtrafniej problem pośredniości i bezpośredniości źródeł ujął I. Ihnatowicz:

Rejestrujac zatem różnicę znaczenia źródła i zakresu zawartej w nim informacji z punktu widzenia twórcy źródła i z punktu, widzenia historyka można zauważyć, że granica, która dzieli źródła w swoim przeznaczeniu informacyjne od pozostatych, pokrywa się w istocie rzeczy z granica dzielaca źródła bezpośrednie od pośrednich ${ }^{33}$.

Przyjmując ten punkt widzenia, wśród pisanych źródeł bibliotecznych do bezpośrednich można zaliczyć księgozbiory lub ich fragmenty bądź pojedyncze książki, natomiast informujące o nich katalogi i inwentarze byłyby juź źródłami po- 
średnimi. Do źródeł bezpośrednich można zaliczyć w tym ujęciu zamówienia, rachunki, księgi rachunkowe, listy płac, ale już na przykład dokumenty informujące o działalności biblioteki opracowane na podstawie dokumentów prymarnych będą żródłami pośrednimi.

Badając historię poszczególnych bibliotek, ale także ich grup (np. bibliotek szkolnych), spotkamy się ze źródłami statystycznymi. Klasyfikację takich źródeł można przeprowadzać zarówno ze względu na ich formę jak i treści, moźliwość zobrazowania procesu historycznego, rodzaju i właściwości poznania zjawiska masowego.

Z punktu widzenia historii bibliotek do szczególnie przydatnych należy propozycja klasyfikacji J. Topolskiego, dzieląca żródła na:

1. pozwalające tworzyć zbiory statystyczne,

2. niestanowiące podstawy tworzenia zbiorów statystycznych ${ }^{34}$.

Jest to istotne uściślenie wlaściwości źródeł masowych i wskazówka metodologiczna przydatna w badaniach nad nimi - wskazuje na to, że należy z zasobu źródel wyodrębnić takie źródla, które umożliwiają badania przy pomocy metody statystycznej.

Stanisław Borowski podzielił natomiast żródła statystyczne na: ewidencje, sprawozdania $i$ dokumenty ściśle stalystyczne, zawierajqce wyniki konstrukcji i odkrycia statystycznego. Biorąc pod uwagę instytucjonalny charakter dokumentów, a więc podmiot wytwarzajacy $i$ cel określajacy przeznaczenie źródta, podzielił je na źródła, które powstały:

1. w instytucjach statystycznych dla celów wyłącznie statystycznych,

2. w instytucjach niestatystycznych, dla celów:

a) wyłącznie statystycznych,

b) statystycznych i użytkowych,

c) wyłącznie użytkowych ${ }^{35}$.

Źródła do historii bibliotek spotkamy w obydwu wyróżnionych grupach, przy czym w wypadku pierwszej z nich będą to źródła wtórne - np. zestawienia Głównego Urzędu Statystycznego dotyczące bibliotek, sporządzone na podstawie ich własnych informacji. Cechą historycznych źródeł statystycznych jest niepowtarzalność. Rzutuje to na błędy popełniane w trakcie analizy źródeł. Można ich uniknạc wtedy, kiedy badacz - oprócz ewidencji sumarycznej, sprawozdań i innych dokumentów - ma do dyspozycji również ewidencję jednostkową. W historii bibliotek pierwszej połowy XX w. jest to sytuacja wyjatkowa ze względu na braki i straty w dokumentacji bibliotecznej, stąd historycy bibliotek najczęściej stosują rachunek szacunkowy. Źródlo statystyczne jest zupełne, jeżeli dokonano obserwacji wyczerpującej i jeżeli dokumentacja tej obserwacji zachowała się w całości w postaci ewidencji, sprawozdawczości lub innych dokumentów. 
Kolejny problem, jaki wiąże się ze źródłami do historii bibliotek w pierwszej polowie XX w., to zastosowanie techniki komputerowej w badaniach historycznych. Rafał T. Prinke twierdzi: Wprowadzenie techniki komputerowej jako jednego z narzędzi warsztatu naukowego historyka powoduje konieczność nowego podejścia do klasyfikacji (...) źródet historycznych ${ }^{36}$.

Dlatego autor podjął próbę kategoryzacji źródeł historycznych pod względem podatności na przetwarzanie komputerowe, wychodząc od systematyki historycznych źródeł statystycznych. W tym kontekście autor skrytykował wspomniany wyżej podział J. Topolskiego, twierdząc, że z każdego żródła można wydobyć jakieś elementy, które wolno poddać analizie statystycznej, choć nie są one „gotowe”. Mając w pamięci próby takiego opracowania dokumentacji strat bibliotek w czasie II wojny światowej, aby poddać analizie statystycznej informacje dotyczące m.in. okoliczności poniesionych strat, można się zgodzić z autorem, że jest to możliwe ${ }^{37}$.

R.T. Prinke zaproponował następującą klasyfikację źródeł:

1. Źródla rejestrujące - posiadające strukturę kolejnych niezależnych zapisów, zwykle o powtarzających się elementach i niewielkim nasyceniu retoryką, których strukturę można stosunkowo łatwo odzwierciedlić w komputerowej bazie danych. W naszym wypadku moga to być pisane źródła biblioteczne, archiwalne i instytucjonalne: np. katalogi, zestawienia, karty czytelników, zestawienia liczbowe itp.

2. Źródła narracyjne - o ciągłym swobodnym tekście, w znacznym stopniu zabarwione nastawieniem autora do osób i zdarzen, np. pamiętniki, dla których strukturę badacz musi sam ustalić i nie będzie ona obejmowała calości źródła.

W naszym wypadku będą to głównie pisane źródła nieinstytucjonalne, ale i część źródeł z pozostałych grup, np. sprawozdania.

Według autora klasyfikacji, mieści się ona w bardziej ogólnym podziale zaproponowanym przez J. Topolskiego - na źródła potencjalne i efektywne. Dla celów przetwarzania komputerowego źródło o wyraźnej strukturze formalnej i niezależnych zapisach jest źródtem efektywnym (zbiorem informacji gotowych do zaczerpnięcia), natomiast źródło narracyjne jest jedynie potencjalnym (z którego historyk może czerpać informacje).

Łącząc oba podejścia, R.T. Prinke proponuje kolejną klasyfikację:

1. źródła informatycznie efektywne - majace wyraźną i jednorodną strukturę wewnętrzną, łatwą do reprezentacji w komputerowej bazie danych,

2. źródla informatycznie potencjalne - pozbawione jasnej struktury, wymagające reprezentacji w formie elektronicznej edycji tekstu.

Wypada powtórzyć, że podobny podzial źródel jest zgodny z doświadczeniami badawczymi wyniesionymi $\mathrm{z}$ prac nad źródłami do historii bibliotek w pierw- 
szej połowie XX w. realizowanych w ramach programu Biura Pełnomocnika Rządu. Także $\mathrm{z}$ owych doświadczeń i z analizy różnych klasyfikacji źródeł historycznych, w tym bibliologicznych, wynika propozycja nowej typologii źródeł do historii bibliotek, przedstawiona w niniejszym artykule jako problem do dyskusji.

\section{Przypisy}

1. M. Mlekicka, Wykorzystanie żródel drukowanych z lat 1795-1918 do badaí nad dziejami ksiqżki polskiej (zarys metodologiczny), w: Z Badan Nad Polskimi Księgozbiorami Historycznymi 3, 1997. s. 25 .

2. K. Migoń, Uwagi o rozwoju i perspektywach historiografii ksiqżki, „Studia o Książce” 5, 1975 , s. 33 .

3. Definicje źródla historycznego m.in. w: G. Labuda: Próby nowej systematyki i nowej interpretacji żrodet historycznych, "Studia Źródłoznawcze” 1, 1957, s. 22; J. Serczyk, Podstawy badai historycznych, Toruń 1963, s. 14; W. Moszczeńska, Metodologii historii zarys krytyczny, Warszawa 1968, s. 77-78; A. Świerzawski, Wstep do badani historycznych. Warsztat naukowy historyka, Łódż 1978, s. 122; J. Topolski, Melodologia historii, Warszawa 1973, s. 265-267.

4. K. Maleczyńska, Żródla do dziejów ksiqżki i bibliotek okresu renesansu, „Studia o Książce” 16, 1986, t. 16, s. 20-30.

5. K. Migoń, Problematyka źródloznawcza w bibliologii, „Studia o Książce” 15, 1985, s. 4-17.

6. A. Greguletz: Einfiuhrung in die Bibliotheksgeschichte, Berlin 1978, t. 1, s. 55-57.

7. K. Migon, Problentalyka źródtoznawcza..., s. 13.

8. M. Kocójowa, Rozważania nad wyborem podslawy źródłowej w badaniach bibliologicznych (na przykladzie okresu niewoli narodowej), „Studia o Ksiąze”" 15, 1985, s. 19-36.

9. J. Fercz, A. Niemczykowa, Podstawy nauki o ksiażce, bibliotece i informacji naukowej, Warszawa 1991, s. 186-192.

10. J. Topolski, Metudologia historii..., s. 265- 271.

11. Wystarczy przypomnieć, że w publikacji Siraty bibliotek w czasie II wojny światowej w granicach Polski z 1945 roku. Wslępny raport o slanie wiedzy, Warszawa 1994, opracowanej przez U. Paszkiewicz, wymienia się 908 pozycji poświęconych problematyce strat bibliotecznych, a wedle M. Dębowskiej (zob. Bibliologia, bibliografia, bibliotekoznawstwo, informacja naukowa. Wybor prac, Warszawa 1999, s. 12-14) w zbiorach Państwowego Instytutu Książki już w 1949 r. znalazło się m.in. kilkanaście tysięcy wycinków prasowych dotyczących książki i biblioteki.

12. Poza omówionymi wyżej można wymienić tutaj m.in.: prace M. Lecha, Materialy do dziejów ksiazki i czylelnictwa polskiego w bibliotekach $i$ archiwach leningradzkich, "Biuletyn Informacyjny Biblioteki Narodowej" 3, 1968, s. 25-27; idem, Akıa nolarialne jako źródta do badań nad księgozbiorami domowymi, „Studia o Książce” 9, 1979, t. 9. s. 187-201: idem, Karloteka źródel archiwalnych do dziejów ksiqżki i czytelnictwa polskiego 1800-1939, „Biuletyn Informacyjny Biblioteki Narodowej” 4, 1964, s. 14-15; K. Glombiowski, O funkcjonalnq koncepcjęnauki o ksiażce, Wroclaw 1970; K. Migoń, Uwagi o rozwoju i perspektywach historiografii ksiażki, „Studia o Ksiażce” 5, 1975, s. 15-44; idem, Metodologia bibliotekoznawstwa i nauki o informacji naukowej, Poznań 1976; S. Siekierski, Pamiętniki jako źró- 
dto badań czytelnictwa, ,Studia o Książce" 6, 1976, s. 3-22; H. Chamerska, Akta hipoteczne i notarialne jako źródla do badań nad ksiegozbiorami prywatnymi XIX-XX w., w: „Z Badań Nad Polskimi Księgozbiorami Historycznymi” 3, 1977, s. 5-22; Z. Gaca-Dąbrowska, Sytuacja w badaniach nad dziejami bibliotek i bibliotekarstwa w XIX i XX w., „Stuđia o Książce” 12, 1982, s. 71-84; A. Żbikowska-Migoń, Wydawnicrwa żódtowe do dziejów ksiażki w Polsce. Stan i potrzeby, ibidem, s. 32-47; M. Dębowska, Bibliologia, bibliografia, bibliotekoznawstwo...; Straty bibliotek w czasie II wojny siwiatowej w' granicach Polski z 1945 roku. Wstępny raporı o słanie wiedzy, red. A. Mężyński, Warszawa 1994: B. Bieńkowska: Kilka uwag i propozycji w sprawie badan księgozbiorów historycznych, „Studia o Książce” 16, 1986, s. 3-15; eadem, Wokót raporlu o stratach bibliotek polskich w czasie II wojny światowej. Problematyka bibliologiczna, w: Symposia bibliologica, Warszawa 1995, s. 86-92; eadem. Zastosowania bibliologii w pracach Biura Petnomocnika Rzqdu do Spraw Dziedzictwa Kulluralnego za Granicq, „Roczniki Biblioteczne" 42, 1998, s. 21 -36; eadem: Biblioteki na wschodnich ziemiach II Rzeczypospolitej. Informator. red. nauk. B. Bieńkowska, Poznań 1998, s. 9-12; eadem: Polyczki ze źródlami bibliologicznymi (na przykładzie urzędowej dokumentacji strat bibliotek w Polsce podczas II wojny światowej), „Roczniki Biblioteczne" 45, 2001, s. 3-27; J. Plis, Źródla dotyczqce strat bibliotek w czasie II wojny światowej. Ocena ich wiarygodności, w: Symposia bibliologica, Warszawa 1995, s. 139-149; H. Laskarzewska, Dziatalność Pracowni Dokumentacji Księgozbiorów Historycznych Biblioteki Narodowej. Wspótpraca krajowa i międzynarodowa; eadem: Zalożenia wstępne dotyczace "IIformatora o polskich księgozbiorach historycznych i powstatych na ziemiach polskich po 1950 r.", ibidem, s. 7-22; S. Waligórski, Wokót raportu o stratach bibliotek w czasie II wojny światowej - problemy informatyczne, ibidem, s. 125-130; Z. Gaca-Dąbrowska, Historyk bibliotek polskich wobec Raportu, ibidem, s. 131-138; J. Puchalski, Badania nad źródtami do dziejów bibliotek w granicach II Rzeczypospolitej w latach 1939-1945. Zarys problematyki, w: E scientia et amicitia ..., Warszawa-Pultusk 1999, s. 151 -157; J. Szymański, Trudności z identyfikacja bibliotek na ziemiach polskich w I polowie XX wieku., „Roczniki Biblioteczne” 45, 2001, s. 41 -54; U. Paszkiewicz, Wybrane problemy dokumentacji zbiorów bibliotecznych na wschodnich ziemiach Rzeczypospolitej do 1939 roku, ibidem, s. 55-90.

13. Wyodrębnienie żródel pisanych jest tradycyjną klasyfikacja żródłoznawcza. Zob. m.in.: M. Handeisman, Historyka, wyd. 2, Warszawa 1928; S. Kościalkowski, Historyka. Wstęp do studiów historycznych, Londyn 1964; G. Labuda, Próby nowej systematyki..., s. 3-52; J. Serczyk, Podstawy badań historycznych...; W. Moszczeńska, Metodologii historii..; A. Świerzawski, Wstẹp do badań hisırı̣cznych...; J. Topolski, Metodologia historii, Warszawa 1973, s. 265- 271.

14. Przykładem może być dokumentacja do dziejów bibliotek w czasie 11 wojny światowej zgromadzona, przechowywana (częściowo przeniesiona do komputerowej bazy danych) w Biurze Pelnomocnika Rządu w Ministerstwie Kultury i Sztuki:

1. kartoteka bibliograficzna (ok. 3000 pozycji),

2. kartoteka źródel archiwalnych (ok. 300 zespołów),

3. ankiety indywidualne bibliotek, które poniosły straty w czasie II wojny światowej (pomocniczo - wykaz bibliotek z terenów II Rzeczypospolitej i Ziem Odzyskanych) - ok. 50000 pozycji. W kartotece tej odnotowane są wszystkie wiadomości odnoszące się do konkretnych placówek wraz z lokalizacja bibliograficzną,

4. ankiety zbiorcze strat na poszczególnych terenach lub w obrębie wybranych typów bibliotek (ok. 250). Zawierają opisy bibliograficzne pozycji, z których zaczerpnięte zostały informacje oraz ich streszczenia (regesty),

5. karty dokumentacyjne piśmiennictwa dotyczącego strat bibliotek, a właściwie szerzej ich losów przed, w czasie i po II wojnie światowej (przemieszczenia zbiorów, rewindykacje itp.). 
Karty zawierają, obok danych identyfikacyjnych źródła (opis bibliograficzny, sygnatura), streszczenia ujęte $w$ formie regestów. Zob. B. Bieńkowska: Potyczki ze żródlami bibliologicznymi..., s. 26.

15. M. Handelsman, Historyka..., s. 45-46.

16. S. Kościałkowski, Historyka..., s. 24, 52-54.

17. J. Serczyk, Podstawy badań..., s. 8-18.

18. I. Ihnatowicz, Źródła do historii XIX i XX wieku, „Studia Źródłoznawcze” 19, 1974, s. 3-4.

19.Zwraca na to uwagę m.in. A. Świerzawski, (idem, Wstęp do badani historycznych..., s. 122-129), który wyróżnił:

1. żródła pisane (tych jest najwięcej),

2. żródła obrazowe albo ikonograficzne (obrazy, rzeżby, dagerotypy, fotografie, filmy, mapy, plany),

3. żródła słuchowe albo dżwiękowe (walce fonograficzne, płyty gramofonowe, taśmy magnetofonowe).

20. Np. Biuro Pełnomocnika Rządu, zbierając dane na temat strat wojennych bibliotek, rozesta10 w kwietnin $1992 \mathrm{r}$, wlasnq ankiete do 150 ważnych bibliotek krajowych, których dzieje siegaly czasów przedwojennych. Zob. B. Bienkowska: Polyczki ze źródtami bibliologicznymi..., s. 18.

21. 1. Ihnatowicz: Źródta do historii XIX i XX wieku..., s.10.

22. Ibidem, s. 3-4.

23. J. Topolski, Metodologiczne klasyfikacje źródet historycznych, (w:) Problemy dydaktyczne nauk pomocniczych historii, Katowice 1972, s. 8.

24. I. Ihnatowicz, Źródta do historii XIX i XX wieku..., s. 6-8.

25. Informator o stratach bibliotek i księgozbiorów domowych na terytoriach polskich okupowanych w lalach 1939-1945 (bez ziem wschodnich), red. nauk. B. Bieńkowska, oprac. U. Paszkiewicz, J. Szymański, Poznań 2000, s. 8.

26. Ibidem, s. 8-9.

27. A. Klossowski, Żródla do badani nad dziejami ksiażki polskiej na obczyźnie, „Studia o Książce" 15,1985 , s. 92.

28. A. Swierzawski, Wsięp do badan historycznych..., s. 122-129.

29. Ibidem, s. 122-129.

30. J. Topolski, Metodologia..., s. 265- 271.

31. B. Kürbis, Metody źródłoznawcze wczoraj i dziś, „Studia Źródioznawcze” 24, 1979, s. 85-86. Według J. Topolskiego krytyka wewnętrzna polega na analizie wiarogodności informatora.

32. H. Karczowa, Reporlaż filmowy i kronika jako źródlo historyczne, „Studia Źródłoznawcze” 16, 1971, s. 28.

33. I. Ihnatowicz, Żródta do historii XIX i XX wieku...., s. 8.

34. J. Topolski, Metodologia .., s. 408.

35. S. Borowski, Charakter i klasyfikacja źródet statystycznych, „Studia Źródłoznawcze” 9, 1964, S. $7-10$.

36. R.T. Prinke, Komputerowa analiza źródet historycznych, Poznań 2000, s. 28-30.

37. S. Waligórski, Wokót raportu o stratach..., s. 125-130. 